\title{
In Memory of Ben Agger
}

\author{
Bob Kunovich
}

Although I had already been an assistant professor for three years at another university, I still had a lot to learn about navigating university and professional life when I arrived in the Department of Sociology and Anthropology at UT Arlington in 2004. As a senior member of the department, a former dean, and a prolific author, Ben Agger was definitely someone that I looked up to. I trusted his opinion because of his experience, despite his disdain for professional attire [Ben frequently wore jeans and a t-shirt to work. I was told that he dressed this way even as dean, although he kept a suit in his office for special occasions. I was jealous because I could never pull this off as an assistant professor].

As a new faculty member, I had tunnel vision in trying to figure out what the expectations were for earning tenure. I found all of my new colleagues to be supportive. I am sure that any one of them would have been happy to meet with me to discuss this. Ben was unique, however, in that he initiated these types of discussions. Assistant professors didn't have to go to him to ask for his input, he sought them out. I can remember attending group lunches with Ben and the other assistant professors where we would discuss publishing norms, teaching load, and other issues important to junior faculty. In these informal settings, Ben was sensitizing us to important issues in our professional lives and providing a sense that we could work to change things for the better. In these off-campus settings, I felt free to discuss contentious issues without being guarded in my opinion and developed bonds of friendship with Ben and the other junior faculty.

Ben was also unique in that his mentorship didn't end when I earned tenure. He was willing to step in to provide guidance and advice that was targeted to where I was in my career. He introduced me to faculty from other institutions, he facilitated connections to series editors (often internationally known scholars I'd otherwise never meet), he reviewed my research record to assess my readiness for promotion to full professor, and he helped me to navigate university politics in a period of institutional change shortly after I became department chair. I didn't always like his advice or agree with his conclusions, but I respected his opinion and I usually came around to his point of view after some critical thought.

In a personal reflection about Ben as a colleague, I would be remiss not to mention that he was willing to put up a good fight, but also to accept the outcome when he didn't win the argument. One example comes quickly to mind - Ben asked to speak briefly with me on my first day as graduate advisor. He questioned the decision to admit a student on probation, fearing that probationary status would impact the student's progress in our program. He wanted me to eliminate it. I made an argument, explained my position, and stood my ground while wondering what I had gotten myself into by agreeing to serve as graduate advisor. After dropping a quick f-bomb, Ben quickly moved on without holding a grudge. He had a short memory for disagreements and was likely to pat you on the back and talk about Oregon football, fishing, or your favorite burger joint when you were done pleading your case.

As department chair, I had the responsibility of calling faculty, staff, and students to notify them of Ben's death. This was the single most difficult day of my career. It is challenging to explain how difficult it was to experience and relive the sense of shock, disbelief, and profound sadness anew with each phone call. It was immediately clear that we had lost an incredible mentor and friend, but gratifying to hear 'what can I do to help?' from so many people. Every once in a while, we are reminded to reflect on the people that have impacted us. I am happy to have had the opportunity to do that now. UTA is a lesser place without Ben, but a much better place for having had him here while we did. 
